\title{
Evaluation of Semi-Diasporic State of Human Mind in the Selected Short Stories by Anita Desai: A Comparative Study
}

\author{
K. M. Wazed Kabir ${ }^{1 *}$, Mahady Hasan NLY ${ }^{2}$
}

${ }^{1}$ Associate Professor \& Chairman, Department of English, Green University of Bangladesh, Begum Rokeya Sarani (300 meter, North Side of, Dhaka 1207, Bangladesh

${ }^{2}$ Research Fellow, Department of English, Green University of Bangladesh, Begum Rokeya Sarani (300 meter, North Side of, Dhaka 1207, Bangladesh

DOI: $10.36347 /$ sjahss.2020.v08i01.008

| Received: 01.01.2020 | Accepted: 19.01.2020 | Published: 30.01.2020

*Corresponding author: K. M. Wazed Kabir

Abstract

Review Article

This paper would like to uphold characters struggling through semi-diasporic conditions like struggling with identity in the short stories by Anita Desai. A keener thought is needed to evaluate a person or situation to attain human ability. A living life in uncertainty is worse than death. The place should be given to every soul that exist and there should be scope for blooming a finer psychological health free from complexity like semi- diaspora. For this purpose, this paper would like to expose Desai's attitudes towards sufferings of human mind through knocking into the door of heart. It makes us realize the truth with remedy to break all those chains by holding human mind in reaching its peak of happiness.

Keywords: Anita Desai, Diaspora, Suno, Games at Twilight, "Scholar and Gypsy," and Mr. Bose.

Copyright @ 2020: This is an open-access article distributed under the terms of the Creative Commons Attribution license which permits unrestricted use, distribution, and reproduction in any medium for non-commercial use (NonCommercial, or CC-BY-NC) provided the original author and source are credited.

\section{INTRODUCTION}

Anita Desai was born on June 24, 1937, in the hill station of Mussoorie, Uttar Pradesh, India. She was one of four children: she had a brother and two sisters, all raised in what was a British colony in their youth. Desai's father D. N. Mazumdar was a Bengali engineer. Her mother, Toni Nimé, was German and met Mazumdar in Germany, then immigrated to India in 1920. Desai has said that it was exposure to her mother's European core that allowed her to experience India as both an insider, and an outsider. Although Desai was formally educated in English, she was raised speaking both Hindi and German in her home in old Delhi. She attributes some of the diversity of her fictional characters to having lived among a mix of Hindu, Muslim, and Christian neighbors while growing up [1].

Desai's formal education was in the English language, and her writing was always in English as a result. She attended British grammar schools, then Queen Mary's Higher Secondary School in New Delhi. She was accepted at Miranda House, an elite women's college in Delhi, and in 1957 at the age of 20 she received a BA with Honors in English Literature from Delhi University. On the heels of her dream of being a writer, she published her first short story the same year she graduated, in 1957. Desai continued to compose and publish short fiction, working for a year in Calcutta and marrying business executive Ashvin Desai on December 13, 1958. They had four children, sons Rahul and Arjun, and daughters Tani and Kiran [2].

While raising her children, Desai maintained her efforts as an author, and completed her early novels while her family grew. Desai lived in Calcutta from 1958 to 1962 , then moved to Bombay, Chandigarh, Delhi, and Poona. Each new location provided an additional rich back-drop for the young author's fiction. Desai became a freelance writer in 1963, and has retained this as her occupation ever since. She addressed her craft in the King interview, "[Writing] is a necessity to me: I find it is in the process of writing that I am able to think, to feel, and to realize at the highest pitch. Writing is to me a process of discovering the truth." Desai contributed to various prestigious literary publications, including the New York Times Book Review, London Magazine, Harper's Bazaar and Quest. Her first novel, Cry, the Peacock (1963), was published when she was 26 years old. In 1965 she published her second novel, Voices in the City, which revealed Calcutta as seen by a group of aristocratic siblings, and she left India for the first time to visit England. While in Europe, Desai gathered material for her third novel, Bye-Bye, Blackbird (1971). She 
directed her focus inward, experimenting with both content and form. 1974 saw the release of her first attempt at juvenile literature, The Peacock Garden, and the next two years yielded another adult novel, Where Shall We Go This Summer? (1975), followed by another juvenile venture titled Cat on a Houseboat (1976) [3].

Although her first three adult novels were not favorably reviewed, her later work garnered growing attention. Her next three adult novels gained her international recognition. Her 1977 novel, Fire on the Mountain, featured three female protagonists each subdued or damaged in some way coming to terms with how place effects their realities [4].

In 1978 she published Games at Twilight, which this paper deals with. It is a collection of short stories where she drew fictional characters in different forms of situation by bringing up the childhood experiences that she went through like the Religious conflict in 1947 in the Indian subcontinent, or the contemporary way of the society which was not acceptable in many cases and also the diasporic feeling that she felt all along. Her childhood observations of various incidents also may put up an effect on the stories too cause the writing comes from the mind and the mind knows what it experiences. The paper will continue to form its shape with the short stories, "Private Tuition by Mr. Bose," "Studies in the Park," and "Scholar and Gypsy" which belongs to the book Games at Twilight [5].

\section{SIGNIFICANCE OF THE STUDY}

As we know about the Diasporic condition where people are rooted out from their geographical location and has to settle in any other place with the struggle of adapting, this paper wants to take it in a semi level and shortened the boundary while the same struggle of body and mind remains. It is always not necessary to be lived in distant parts to have the kind of diasporic feeling which run by the minds. It is also possible within the area of regular human lives that researchers want to state as a semi-diasporic condition. We should keep the fact in our mind that the psychological sides deriving from this semi- diasporic condition hold a more significant influence over life and they should be assess carefully by people living around or else disaster can take place and life will be led in harmful way.

\section{Theoretical Framework}

The paper deals with defense mechanism of human mind and problems like Existential crisis in a semi-diasporic state. Repression and Denial are two type of defense mechanism stated by Sigmund Freud. According to Freud the human mind is divided into three parts named Id, Ego and Superego. The Id is the unconscious part that should be satisfied by any means and all the demand derives from it. The super-ego plays the role of conscience and prevents the harmful urge of
Id by preventing it to happening. The ego reasons between outer world and fulfills the demand of Id in order to maintain the psychological balance. Repression is the unconscious mechanism employed by the ego to keep away the disturbing or threatening thoughts from becoming conscious. It is another way of protecting the stability of mind where the Id stays in state of satisfaction with the balance created by Ego. Reflection of Repression in the character Mr. Bose is mentioned in the short story, "Private Tuition by Mr. Bose." Another defense mechanism is Denial that involves blocking of external events which harms the psyche of a human. The process hides the cause from the mind in order to protect the mind from awareness of it. If some situation is too much to handle then the person just refuse to accept it and it can be found in Suno from the short story, "Studies in the Park."

The Existential crisis is another theoretical term deals with human mentality. It is the personal thinking of oneself, who thinks himself as inferior or useless or valueless. Tied by depression or inevitably negative speculations the person seem to lose the goal of living or purpose in life. It is similar to the thinking style of Pat in the short story, "Scholar and Gypsy."

\section{LITERATURE REVIEW}

Writers of diasporic Indian English literature can be divided into two categories: first generation immigrants and second generation immigrants. First generation immigrant writers become representatives of immigrants who have lived a considerable period of time in their motherland and now are trying to adapt into new contexts after immigration whereas second generation immigrant writers represent the descendants of first generation immigrants Amitav Ghosh, Salman Rushdie, Kamala Markandaya, Bharati Mukherjee, Chitra Banerjee Divakaruni, Anita Desai, Kiran Desai, Vikram Seth, Meena Alexander, Sunetra Gupta, Aravind Aditya, Vikram Chandra, Neel Mukherjee, Hari Kunzru, Thrity Umrigar, Sameena Ali, Kalyan Rai, Raja Rao, Anurag Mathur are some of the prominent writers of diasporic Indian English literature. It is considered that the portrayal of Indian immigrants in fiction written by diasporic female Indian writers has more subtlety and sensibility. As mentioned by Ashalata Kulakarani, Latha Rengachari in her article Debating Expatriate woman's writing:

In their aim at self-definition and the expression of their expatriate experiences, women from 1970s onwards chose to use literature. Literature became a means of establishing autonomous selfhood. Third world women sought to find words and forms to fit their experiences and have chosen narrative strategies like the autobiography and the quest novel to do so. They use the auto-biography to give shape to an identity grounded in these diverse experiences of expatriation and self-definition. 
Thus it is evident that there is a significant role of female writers in diasporic Indian English fiction which is enriched with experiences and mentalities of Indian diaspora. Anita Desai, who was born in 1937 in Dehradun and immigrated to England and America respectively is another prominent diasporic female Indian writer. Her novel Bye Bye Black Bird (1971) portrays the immigrants who are in search of their identity in another land. Additionally, it carries the viewpoint of young immigrants, aspects of discrimination, east- west cultural dichotomies, disappointment and isolation faced by immigrants in a post- colonial context.

Anita Desai's novel Bye-Bye Blackbird presents a vivid description of immigrant lives in an alien land, and reveals deep into the psychology of its characters. It examines the encounter of east and west and talks about the vanity, the perplexity and dilemma of immigrant Indians of their existence in England. The novel highlights the susceptibility and vulnerability of Indian minds to English culture and hence to rich England, that enchanted them by its magical grace and tranquility; enthralled them by its abundance and sophistication. But at the same time, it also entangles, enslaves and disdains them with its authority, empire and disapproval for being, "colored Indians=Blackbird," is the term given by the author to the immigrant Indians thus exposing the social disparity and discrimination prevailing in England. Adit's character deals with the identity crisis in the novel. Though he projects himself much at home in England something draws Adit back to India. He is tormented between his longing for his homeland, India, and his love and fascination for England. In the beginning he wanted to dazzle everyone with his oriental wit and fluency. He is much attracted to the England life style and tries to imitate the England people. It is the sense of self-description, as he tries to consider himself as an Englishman. It is obvious when he tells Dev "Come on, yar, be a man, an Englishman. Adit's love for England is shown through - $\mathrm{O}$ England's green and grisly land, I love you as only a Babu can. Although he is ill-treated and insulted as an Indian immigrant, he still loves England and admires all the English ways of life. It is apparent when he declares - well, I always say English cooking is wonderful." After spending many a year in a foreign land, the immigrants still are known as expatriates; and their past keeps haunting them. Many of them keep wandering aimlessly along the margin of the two countries and the past becomes unrecognizable. At this juncture the immigrant faces the crisis of identity. Very often the immigrant tries to negotiate a new space for him but experience a sense of dislocation. The immigrant's inability to adapt to the new world, takes its toll on him at the mental, psychological and spiritual spheres. At this point, they begin to search for their roots and this process leads towards the relocation of their identities. This is when the self-analysis sets in.
All the characters of the novel make self- discovery and very often find themselves alienated.

Nostalgia is another aspect which plays havoc with the immigrant's identity. His desire for the past makes it difficult for him to relocate himself in the adopted country. This is the focus of Anita Desai in this novel-the quest for self and survival of self. The diasporic characters are caught up in the conflict between two countries and its codes. This living between two cultures creates a need and desire to fashion new identities.

\section{Anita Desai in the Gaze of Critics}

It is an apt paradox that, at 61 , the Delhi novelist, who has only recently found freedom in the life of the itinerant academic, should be escaping India and rushing to embrace it. Salman Rushdie once described Desai's subject as solitude. Yet while her main characters tend to be isolates and outsiders whether Indian or foreigners in India - her fiction probes the tensions between their desired privacy and detachment, and the powerful family and social ties that both stifle and sustain.

First published in the early 60s, Desai is widely praised as the finest of her generation of Indian writers in English, and one of few who had an international reputation, alongside RK Narayan, before the post-Rushdie wave of the $80 \mathrm{~s}$ and $90 \mathrm{~s}$. She was twice shortlisted for the Booker prize for the novels many think her best: Clear Light of Day and In Custody - the latter made into a film by Ismail Merchant. And thanks to the recommendations of the Macpherson report on Stephen Lawrence, Desai now has a place on the national curriculum beside the Nobel prizewinners Derek Walcott and Wole Soyinka.

The fiction writer and critic Aamer Hussein sees Desai's subject as the changing fortunes of the Indian middle classes from western-educated to struggling lower-middle- class - and the western encounter with India. But he cautions against mistaking her novels' elegant surfaces for their essence. People use the term 'water color' about her work, but it can be expressionist. Beneath the calm surface you sense the violence, with women on the edge, like widows who die of drink, or devouring characters like Nur, the decadent Urdu poet of in Custody. Professor Shirley Chew of Leeds University, who is writing a book on Desai, adds: "The strong undercurrent of violence comes out through powerful imagery - of heat, bird cries, the brutal beating of a horse, or Nur surrounded by pigeons on the balcony, being preyed upon."

Desai has been compared to European women writers of the last century or early 20th, hankering for a room of one's own. "People are very threatened by the idea that you go away and in secrecy and silence do something mysterious," she says, "I don't think I felt 
like a writer till I first came to England, where people had read my books." While family friends recall Ashvin as a proud and supportive husband, Desai insists: "My writing career was entirely subservient to being a wife and a mother. I lived the life of the typical Indian housewife; wrote in the gaps and hid it away, kept it secret."

Putting aside all of the criticism Desai knew how to hold herself within herself. In her novels she follows her own instinct, which is a kind of compulsion, an inner urge. She writes down the scenes and impressions, moods and emotions. Being a creative writer, she is conscious of its true value while writing. Desai says that this has become such a deeply ingrained habit, it is like chain smoking: "I chain - smoke with words, with books. There is a difference of course what begin, as self-indulgence eventually becomes a selfdeceptive" [6].

\section{Textual Analysis \\ A Juxtaposition of Love}

When we look into a short story, "Private Tuition by Mr. Bose," we will see an aged Indian man Mr. Bose who gives tuition on language such as Sanskrit and Bengali to his students including a boy Pritam and a girl Upneet. While teaching Sanskrit to Pritam in the balcony, most of the time Mr. Bose doesn't concentrates on how Pritam is studying rather he puts his attention by observing his wife and his child. He enjoys his time by playing eye on eye with his wife and when Pritam complains on the fact he uses harsh replies to suppress him. The scenario gets a rapid change while his other student Upneet arrives after Pritam departs. Mr. Bose plays a role of a lover with the young girl Upneet and Upneet seems to express her irritation by a comic way which shows that she is a girl who likes to be entertained. The sound of footsteps coming from the staircase hits right into the heart of Mr. Bose as it pounds with a faster rate of heart bits. His wife loses all the attention with the emerging of Upneet cause the excitement of making love with an young lady gives a whole new world of enjoyment in his life. The cries of his young child puts him out of concentration and he shouts toward to his wife to somehow stop the child cause it was creating enough disturbance that he was unable to teach Upneet poems in Bengali. His wife gets annoyed as she realizes that the extra attention toward Upneet is not usual at all. But Mr. Bose didn't care much as the feeling of a new love overtakes all other worries. Mr. Bose is sort of surprised about the fact of teaching poems in Bengali to Upneet and sees no benefit on that but still he continues to give lessons to that girl not for the sake of teaching but for the sake of having the appearances of the girl in front of him. He loves to hear the same thing again and again coming from Upneet and continues to roll his eyes on the beauty of the young girl. When the girl leaves he returns to his older state and continues his older role of being a loving husband toward his wife with the remaining glimpse of feel that he acquired from the young girl Upneet during the tuition time. A man living on a role of a two sided love with an equal feeling of joy gives us a semi-diasporic condition where he isn't ready to leave his older love with having a new one on his side. He feels inferior in front of Upneet as his mind think like, "Under this Upneet's gaze such ordinary functions of a tutor's lufe as sitting down at a table, sharing a pencil and opening a book to the correct page became matters of farce, disaster and hilarity." (Games at Twilight, 15) Upneet is a new world where he landed his feet but at the same time his root world lies at his wife to whom he can return with the right of being his wife. He just can't deny the fact of loving Upneet as she became his new shelter which revives his feeling of love although a insecurity lies in there. Upneet is like the adapting space where Mr. Bose gets his vibe but not the freedom of doing anything he want but in the case of his wife he is ensured like a motherland who is there to take him on. This is how the state of semi-diaspora is created where Mr. Bose tries to live in love where he doesn't belong to and also can't resist himself by not doing so and staying faithful to his wife. His condition is like as Anita Desai stated in the story as, "He couldn't understand how this two halves of the world holding so carefully together, sealing them with reams of poetry, reams of Sanskrit, had split apart into dissonance." (Games at Twilight, 17) Feeling ashamed to return again, Mr. Bose puts himself together through the repression mechanism where his ego was employed in keeping away the thoughts of being scolded or being betrayed and gets present before his wife and shows that the love for her isn't diminished and he have the perfect proportions of love in his heart for his wife which displays semi-diasporic state that he is rearing inside of himself.

\section{An Unchained Mind}

"Studies in the Park" is another short story where we have a college final exam candidate Suno from a town in India. Suno is sort of frustrated as he thinks his life is nothing but a soul who is created for achieving success in exams and delivering delight in the face of his family members. He has a father who counts the expenditure of the family to pros and cons and always yells at Suno to read more and more and more to become the achiever of extra-ordinary result which will lead him to getting an exquisite job in order to settle his life along with the family. All study and no play didn't made Suno dull like Jack but gave birth of an utter frustration that he wasn't able to remove at time. $\mathrm{He}$ tried to concentrate as there were no other choices but the disturbance all around whole house was preventing him again and again from concentrating as he already had a jumbled mind. He left all the chaos behind and came to the streets looking for a quiet place to study and he was directed to a nearby park from the tea stall that he usually attends. A gram vendor suggested Suno to go in because there were more like Suno who was studying there and said he left study a long time ago by 
singing, "I'm glad that I never went to school, I am a bul-bul, I live in paradise." (Games at Twilight, 28) The park seemed so suitable to Suno that he became amazed and thought that why didn't he think of this place before and started to get a hang of it. He saw more of like him in there and also more sides of lives that he didn't have an inch of idea about those. It became the place more comfortable than the home but as time passed he figured out the sides that was not in his reach to stand. The yoga people's movement of the limbs was funny to him and their laughing face pose hus-mukh seemed like Gargoyles with colored tongue sticking out. People taking oil massage disgusted him and group of people chatting within themselves about philosophy by throwing references of Upanishad or the Bhagavad Puranas was pointless to Suno. He stated that, "certainly it was the mind above the body for these old coots" (Games at Twilight, 26) but there was nothing to admire them at all for the topic they were diverge into. $\mathrm{He}$ became restless again like, "read without seeing and slept without sleeping." (Games at Twilight, 29) But a sudden incident changed it all as one day he saw a Muslim woman wrapped in a black borkha was lying in the lap of her husband above a bench. He saw a world of love in the eyes of that Muslim woman which brought a rapid change to the mind of the Suno and suddenly he figured out the meaning of life and that was to live and die with eyes full of love and that was it. Suno gives another reflection of a semi-diasporic condition where his root shelter is the home and the new shelter was that park beside of his house. While his nerve was getting wrecked inside the home by only dealing with the expectations of the family and also not getting the desirable environment to go on and as a result a search for a new habitation of mind gave him the park. He denied the whole system that was he going through and his mind confessed that, "our books seemed attached to our hands as though by roots, they were part of us, they lived because we fed them." The park also started to distort his attentions as he saw contortions of yoga people whose movements looked like an ape to him and he was just the opposite of it as he stated that, "what's the body compared to the soul, the mind?" (Games at Twilight, 26) But his displacement from home to park bore fruit as he observed the incident of the Muslim woman and man which gave his mind a freedom from the shackles in which he was bind into. His mind was freed from the thought about the books which was, "They were parasites and, like parasites, were sucking us dry." (Games at Twilight, 28) The denial defense mechanism started to work inside of himself to protect his mental stability from the stress that he were having and he found the inner peace in that park. His mind was free from worrying about studies anymore as his mind denied the total idea and importance and massive pressure it had in his mind with opening a new window of seeing life in park. It was like the new place gave a whole new world to him but he couldn't forget his thought of his mother at home cause she was the only one who gave him ultimate peace of acceptance in all the times. So it ended in the point where Suno left in a semi-diasporic condition of leaving his heart to his mother at home and wandering into the park to get another glimpse of that life changing look that the Muslim woman gave to her husband which set his mind free to roam around in a whole new world of living and left him with the thought that, "I never have but I keep hoping, wishing." (Games at Twilight, 33)

\section{Holding the Ground}

The last of the trio of the short story is the, "Scholar and Gypsy" is the story that portrays the journey of an American couple named David and Pat who were globe trotter and was set on a journey of observing the lifestyle of people in India in order to fulfill a paper that was to be accomplished by David. Their first destination in Bombay sets Pat in a restless mood that was created by the warm weather and more actively by the people who were nothing but like the primitive race to her. David insisted that the people in Bombay can be fitted at any cocktail party in even New York but Pat refused it with her statement that they did not have the polish or the smoothness or the softness and so on. They moved from the wild jungles of the city of Bombay full with primitive people as stated by Pat to Delhi. But Delhi was dryer than Bombay and Pat again put up in a struggle to hold herself together. David was getting more and more depressed by the activities of Pat and cried to her that, "Climate isn't important, Pat - rise above it, there is so much else." (Games at Twilight, 112) She tried her best to remove the thinking of not being able to become the fellow gypsy that David wanted to see in her. They moved again and finally Pat was to find herself in Manali which was like an overgrown village to David. Pat got intimate with the religious people of a temple situated in there and got attached to it pretty quickly and was indulged in that so much that she stated the tall people wearing a rob as Christ and mistook the Hindu temple as a Buddhist one. David got outrageous and tried to put a stop at it by putting negativity in his words about the people as stoned ones and also yelled at Pat as she was going out of her mind. But Pat was much calmer than she was in the whole wandering through other cities of India and held herself so tightly in there that David was like in a mess from where he couldn't get out whatever way he tried or whatever word he said. He decided to leave but met an accident at the bus stop where he was medicated by another American. At the end he was in the point of leaving India without his Pat as she was settled in the new place. The psychology of Pat shows us the semidiasporic condition that she was going through. After entering into India her life spirit was decreasing ounce by ounce and all the cheering from her husband was in vain as its natural for the human kind to lose him or herself while they are rooted out from the lap of motherland. She expressed with utter disgust about India to David: 
You know, down in those horrible cities, I'd gotten to think of India as one horrible temple, bursting, crawling with people- people on their knees, hopeless people- and those horrible idols towering over them with their hundred legs and hundred heads- all horrible...(Games at Twilight, 128)

The suitable mind and body get worn up in the whole new environment while trying to adapt. But somehow she was able to find the essence of living in Manali and was slowly getting out of the hold of David as Anita Desai stated, "As she grew browner from the outdoor life and her limbs sturdier from the exercise, it seemed to him she was growing into some tough, sharp countrywoman who might very well carry loads, chop wood, haul water and harvest but was scarcely fit to be his wife -his, David's." The statement gives the picture of a person who settled on another part of the land where she doesn't belong and by growing roots in there she became unfit to the land where she belongs to. Pat was going through existential crisis in the crowd of a foreign land and her thought about she is not suitable was growing stronger and stronger but all worries diminished at the moment while she seemed to find her ground at Manali. The interactions of familiar race in foreign land works like a massive support on the diasporic condition that we can observe in David's action while he met an American doctor. That was the sigh of relief that a person going through a crucial situation can have, and his negativity toward Pat about growing love for another place where she isn't meant to be is like the familiar tone against the diasporic people.

\section{RESULTS}

Human should behave more human like towards the other humans. There will be people like Mr. Bose having a separate love life along with a complex understanding in nature and there are ways of contemporary society which are rolling over the minds of young ones like Suno and people like Pat also exist around us, roaming like gypsies to find their true-self to hang on. People are struggling as they fighting against their minds or the ideas implemented in their minds or trying to put emphasis on the point that will direct them into a world where their mind will be free. Human alike thinking within free mind is what makes the human separate from other animals. For this, differentiations, limitations and other boundaries should be removed which endangers human mind and drives it into madness and state like semi-diaspora. The problems are created with their rules and it is also the responsibility of the social being to be a little bit more socialize by playing a supportive role at the side of the men going through psychological crisis. A single step can remove the sufferings of a single life when a human will be convenient enough to understand another human in the way of accepting about the way they are and also a little bit more freedom in living can change the course of the life for a greater good.

\section{CONCLUSION}

We should behave with a much broader perspective whenever we will locate persons struggling through semi-diasporic conditions like struggling with identity and more. A keener thought is needed to evaluate a person or situation like this and for attaining such ability we should develop a keener insight to see through the situations like this where soul can be saved.

A living life in uncertainty is worse than death. We should not let the people become living dead before they die. The place should be given to every soul that exist and there should be scope for blooming a finer psychological health free from complexity like semidiaspora. Anita Desai painted all those sufferings of human mind in such a way that it knocks into the door of our heart and make us realize the truth and we should stick with that truth and should come with remedy for breaking all those chains that holds human mind in reaching its peak of happiness.

\section{REFERENCES}

1. Chakranarayanan, M. Style Studies in Anita Desai. New Delhi, Atlantic Publications \& Distributors. 2000.

2. Desai A. Cry, the Peacock. New Delhi: Orient Paper Bags. 1980.

3. Dhawan RK. Fiction of Anita Desai. New Delhi: Prestige Book. 1991.

4. Kulkarni A. Indian English Women Fiction, Muse India. 2015.

5. Rao BR. The novels of Mrs. Anita Desai. Delhi: Kalyani Publ. 1977.

6. Dalmia Y. An Interview with Anita Desai. The Times of India. 1979 Apr 29;29. 